Vol.45, n. 4 : pp. 491-498, December 2002

ISSN 1516-8913 Printed in Brazil

\title{
Dynamic of Decapod Crustacean Larvae on the Entrance of Guanabara Bay
}

\author{
Lohengrin Dias de Almeida Fernandes ${ }^{1 *}$, Sérgio Luiz Costa Bonecker ${ }^{1}$ and Jean Louis \\ Valentin ${ }^{2}$ \\ ${ }^{1}$ Departamento de Zoologia, Instituto de Biologia, Universidade Federal do Rio de Janeiro. Centro de Ciências da \\ Saúde, Av. Brigadeiro Trompovsky, s/n. Cidade Universitária, Ilha do Fundão, Rio de Janeiro, CEP 21941-590. \\ ${ }^{2}$ Departamento de Biologia Marinha, Instituto de Biologia, Universidade Federal do Rio de Janeiro.
}

\begin{abstract}
In the present study, we observed seasonal variations in the density of decapod larvae as well as changes in density related to diurnal and tidal cycles. Among the decapod larvae collected, portunids and grapsids were the most abundant, especially during nocturnal ebb tides and near the surface. The same results were obtained in late winter (September) and late summer (March). These results demonstrated a flow of decapod larvae from Guanabara Bay to adjacent coastal waters. Luciferid (Lucifer faxoni) was the only group with high densities during flood tides and we suggest this is an evidence of L. faxoni larvae entering Guanabara Bay in late winter. Probably these changes in distribution of Lucifer faxoni among winter and summer were related to reproductive cycle in the bay. For the portunids, grapsids and ocypodids, a similar dispersion strategy was observed towards adjacent coastal waters in the surface during nocturnal ebb tides.
\end{abstract}

Key words: Crustacea Decapoda larvae, Zooplankton, Vertical Distribution, Vertical Migration, Dynamic, Guanabara Bay

\section{INTRODUCTION}

Most estuarine decapod (McConaugha, 1988) and non-decapod larvae (Stancyk and Feller, 1986; Wolanski and Sarsenski, 1997) tend to be dispersed under local hydrodynamic patterns toward oceanic areas. Some of them can survive in oceanic oligotrophic waters, such as the Cancridae and Portunidae, but most species display special strategies to keep themselves inside estuaries, or to come back soon, such as the Xanthidae and Ocypodidae (McConaugha, 1988).

Staying in eutrophic estuarine waters can be an advantage considering the availability of food resources, however, this is countered by higher pollution levels and higher predation rates in estuarine waters. The way in which planktonic decapod larvae stay in estuaries or reach oceanic waters is mainly by regulating their depth within the water column. Staying near the surface during ebb tides, as observed for portunid larvae (Sandifer, 1975), may result in fast dispersion towards the ocean. In the same way, staying near the bottom may result in low dispersion. There are other strategies affecting the retention and the dispersion of larvae from estuaries, which include fast development, ontogenetic vertical migration,

\footnotetext{
*Author for correspondence
} 
and epibenthic behaviour (Epifanio, 1988; Schwamborn, 1993).

Guanabara Bay has been the focus of attention for a ten-year multidisciplinary study carried out by the Federal University of Rio de Janeiro. There are many reasons for this effort, all of them related to the environmental changes observed in Guanabara Bay both before and during the study. Examples of environmental changes include: increased silting rates (Amador, 1997), changes in seasonal patterns of salinity and temperature (Paranhos and Mayr, 1993), decreased water quality (Kjerfve et al., 1997) and changes in the composition and distribution of the zooplankton community (Nogueira et al., 1989). These changes are likely to impact on fisheries and the large number of people who depend on them. For example, according to Almeida (1993), more than 6,000 people removed about 10 tons of shrimp per month from the bay.

The only specific study about decapod larvae in this bay was done by Oliveira (1962), in which some larval stages of Chasmagnathus granulata were described. Nogueira et al. (1989) investigated total zooplankton community in Guanabara Bay. They found distinctive communities within the bay and at the entrance to the bay and implied that a gradient existed from the bay to continental shelf waters. Their study did not focus on decapod larvae. Recently, Valentin et al. (1999) published a review on the planktonic system in Guanabara Bay.

The aim of this paper was to describe the dynamics of decapod larvae at the entrance of the Guanabara Bay.

\section{MATERIALS AND METHODS}

Considering the influence of depth regulation behaviour upon the dynamics of the larvae, to follow the distribution of decapod larvae in the water column during several tidal cycles was chosen and proved to be an interesting method to estimate the larval flux between Guanabara Bay and the adjacent coastal area.

This study was carried out at a fixed point $\left(043^{\circ} 09.0 \mathrm{~W}, 22^{\circ} 54.4 \mathrm{~S}\right)$ near the entrance of Guanabara Bay (Fig. 1). The point was located in the main channel, at approximately 30 meters depth and high current speeds.

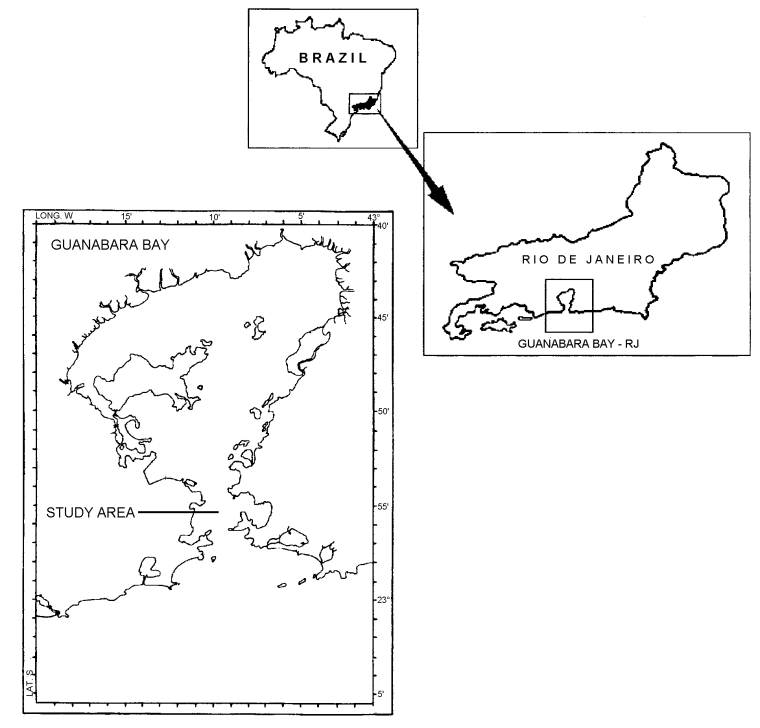

Figure 1 - Study area (black line in detail) inside Guanabara Bay, Rio de Janeiro State.

Zooplankton was collected over six days, three days in late winter (September 13 to 15,1995 ) and three days in late summer (March 13 to 15, 1996). In each period, 20 samples were collected in horizontal hauls, ten at the surface and ten near the bottom $( \pm 25 \mathrm{~m})$. The hauls occurred during the night and the day with intervals of 6 hours between each catch. A cylindrical-conical net with a mesh size of $200 \mu \mathrm{m}$ and equipped with a calibrated flowmeter was used. Samples were taken during ebb and flood tides and stored immediately in 4\% formaldehyde solution, buffered with borax. Water temperature and salinity data, from surface to near the bottom were registered at one-meter intervals by means of a conductivitythermosalinometer ( LabComp). Wind direction was also recorded during sampling.

Decapod crustacean larvae were sorted, identified and grouped as following: 1) Luciferidae; 2) Ocypodidae; 3) Xanthidae; 4) Portunidae/ Grapsidae; and 5) others Brachyura (including Gecarcinidae, Pinnotheridae and Majidae). Other observed decapods included non-brachyuran and non-luciferid decapods, mainly Caridea and Anomura larvae, and was called simply 6) other decapods. Portunids and grapsids were grouped together because of the similarities between them. Differences in the densities among surface and bottom, ebb and flood, and day and night samples in winter and in summer were compared separately by non-parametric Kruskal-Wallis ANOVA 
(Siegel, 1975). Three winter samples were excluded from the ANOVA test because they were made during a non-typical tidal flux. The interaction of tide and light factor was excluded from the analysis of variance because of the low number of samples. Before ANOVA, data were homogenised according to Ibanez (1976) by log $(\mathrm{x}+1)$.

\section{RESULTS}

Water temperature in winter varied from $24.5^{\circ} \mathrm{C}$ at the surface to $22.5^{\circ} \mathrm{C}$ at depth. The range of water temperature was larger in summer than in winter. Surface water temperature was about $26.5^{\circ} \mathrm{C}$ and near the bottom about $22^{\circ} \mathrm{C}$. The termocline was at 12 meters depth.

Salinity data followed the same pattern of variation as water temperature, with a larger range in summer than in winter. Salinity ranged from $32 \%$ at the surface to $34.5 \%$ near the bottom in winter and from $26 \%$ to $36 \%$ in summer. The lower values indicated the influence of river inputs to Guanabara Bay.

Densities of decapod larvae ranged from 0.4 to 788 ind. $\mathrm{m}^{-3}$ in winter and from 1.3 to 612 ind. $\mathrm{m}^{-3}$ in summer. In winter, the average density at the surface and near the bottom was 281 ind. $\mathrm{m}^{-3}( \pm 248$ ind. $\left.\mathrm{m}^{-3}\right)$ and 24.3 ind. $\mathrm{m}^{-3} \quad\left( \pm 24.5\right.$ ind. $\left.\mathrm{m}^{-3}\right)$, respectively. In summer, the average density at the surface and near the bottom was 169 ind. $\mathrm{m}^{-3}( \pm 216$ ind. $\left.m^{-3}\right)$ and 11 ind. $m^{-3} \quad\left( \pm 7.7\right.$ ind. $\left.m^{-3}\right)$, respectively. In both periods, highest densities were found at the surface during nocturnal ebb tides, while the lowest values occurred during the diurnal flood tides (Figs. 2 and 3).

Depth and season influenced significantly the density of total decapod crustaceans recorded $(\mathrm{p}<0.01$ and $\mathrm{p}<0.05$, respectively), as well as the brachyuran density (Tables 1, 2 and 3). Depth / tide and depth / light interactions were shown to significantly affect brachyuran density in the winter (Table 1). So, the highest brachyuran densities observed near the surface during the nocturnal ebb tide were significantly different from that recorded during the day in both the surface and near the bottom, and during the night near the bottom.

Among the decapod larvae collected in winter, brachyuran zoeae were the most abundant group, frequently representing more than $90 \%$ of total decapod density. Highest densities, 400 to 700 ind. $\mathrm{m}^{-3}$, were found at the surface during nocturnal ebb tides (Fig. 2). Although this group was dominant near the bottom too, their population density never reached more than 73 ind. $\mathrm{m}^{-3}$. In summer, brachyuran zoeae were also the most abundant group, mainly during the ebb tide and at the surface. During the day, brachyuran densities were lower than 60 ind. $\mathrm{m}^{-3}$, and near the bottom, lower than 14 ind. $\mathrm{m}^{-3}$. In both summer and winter, high densities were coincident with high tides. These high values occurred before midnight in winter and after midnight in summer.

Among the brachyuran zoeae collected, portunids and grapsids were the most abundant, representing more than $90 \%$ of total brachyuran zoeae. Xanthids, ocypodids, and other brachyuran such as pinnotherids, majids, and gecarcinids, occurred in low density.

Portunid and grapsid density ranged between 0 and 651 ind. $\mathrm{m}^{-3}$ with highest densities at the surface in both winter and summer. Significant differences $(p<0.05)$ in density values between nocturnal and diurnal samples were only found in the summer (Table 2). No significant differences were found in densities between ebb and flood tides, neither in the winter nor in the summer sampling periods (Table 3). Ocypodid density varied from 0 to 132 ind. $\mathrm{m}^{-3}$. During both winter and summer, highest densities occurred at the surface in nocturnal samples (Tabs. 1 and 2). As for Portunid and Grapsid larvae, no significant association with tide or season was found (Tables 1, 2 and 3). The density of Xanthids was lower than portunids, grapsids and ocypodids, ranging between 0.1 and 115 ind. $\mathrm{m}^{-3}$. No significant differences in sample density between summer and winter were found (Table 3). In summer, the highest xanthid densities occurred at the surface during nocturnal ebb tides (Fig. 3). Some xanthid megalopae were also collected from near the bottom, mainly during flood tides.

Others Brachyura (mainly pinnotherids, majids and gecarcinids) occurred in low densities. It's density varied from 0 to 87 ind. $\mathrm{m}^{-3}$. As with the xanthid larvae, no significant correlation between depth and tide were found in the winter samples (Table 1). In summer, the population densities were associated with depth and tidal factors (Table 2). Among the non-brachyuran, Luciferidae (Lucifer faxoni), Sergestidae (Acetes americanus), Alpheidae, Palaemonidae, Pasiphaeidae (Leptochaela $\quad$ sp.), $\quad$ Porcellanidae 
(Megalobrachyum sp.), Paguridae, Diogenidae, and Callianassidae were also collected.

Population densities for the Luciferidae (L. faxoni) ranged from 0.003 to 30 ind. $\mathrm{m}^{-3}$ in winter and from 0.2 to 93 ind. ${ }^{-3}$ in summer. High values in winter were found twice at the surface during flood tides (Fig. 4). Although population densities were low near the bottom in winter $(3.0 \pm 3.6$ ind. $\mathrm{m}^{-3}$ ), the density of $L$. faxoni increased to 12.3 ind. $\mathrm{m}^{-3}$ with the onset of southerly winds (Fig. 3, Station 6). The highest density values for $L$. faxoni were found in the summer and again twice at the surface during the night, but now during ebb tides not flood tides. Initial low values found near the bottom increased during nocturnal flood tides.

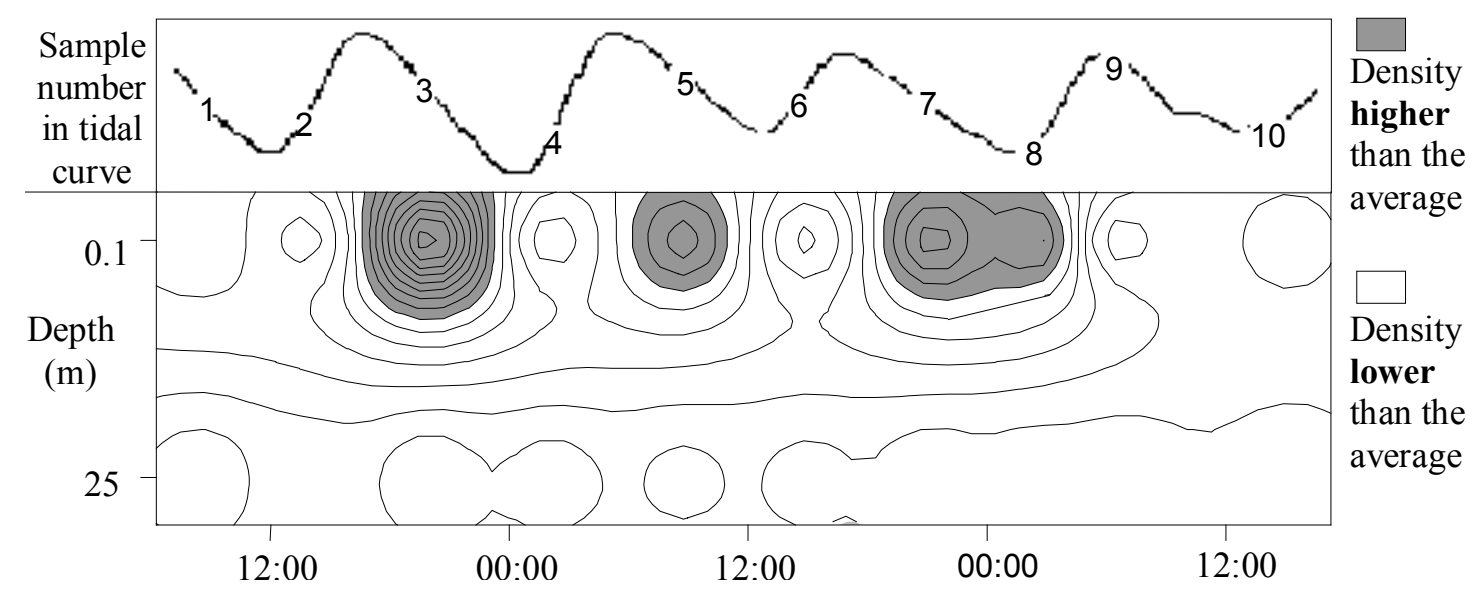

Figure 2 - Vertical distribution of brachyuran zoea during the days of sampling in winter in Guanabara Bay - an example of vertical distribution indicating the flux toward the shelf waters associated with both the nocturnal and diurnal ebb tide. The station numbers and the tidal curve were showed on the top.

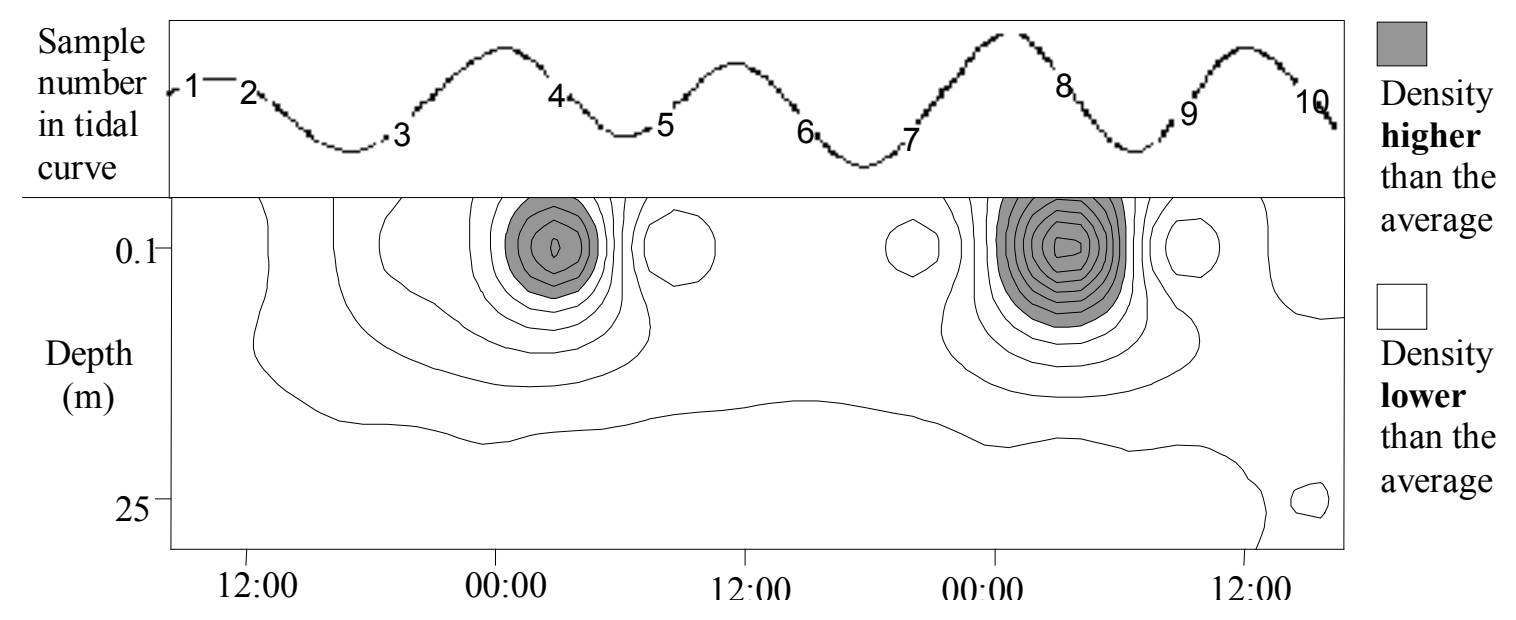

Figure 3 - Vertical distribution of xanthid zoea during the days of sampling in summer in Guanabara Bay an example of vertical distribution indicating the flux toward the shelf waters associated with nocturnal ebb tide. The station numbers and the tidal curve were showed on the top. 


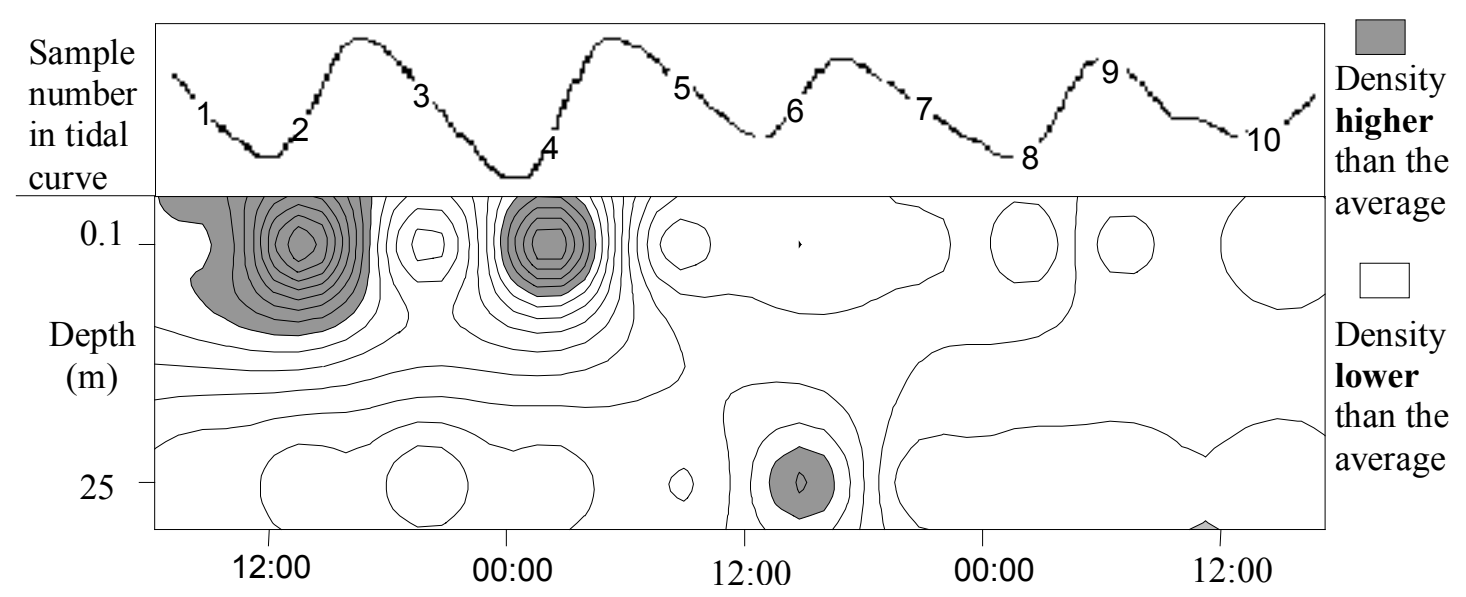

Figure 4 - Vertical distribution of luciferid during the days of sampling in winter in Guanabara Bay - an example of vertical distribution indicating retention inside the bay associated with flood tide. The station numbers and the tidal curve were showed on the top.

Table 1 - Analysis of variance (Anova) of density (ind.m-3) in response to depth, diurnal and tidal cycles, and their interactions in winter samples. Significant relations are marked with $\mathrm{p}$ level.

\begin{tabular}{lccccc}
\hline & Depth & Light & Tide & Depth/Light & Depth/Tide \\
\hline Total decapod & $\mathbf{p}<\mathbf{0 . 0 1}$ & Ns & Ns & $\mathbf{p}<\mathbf{0 . 0 5}$ & $\mathbf{p}<\mathbf{0 . 0 5}$ \\
Total brachyuran & $\mathbf{p}<\mathbf{0 . 0 1}$ & Ns & Ns & $\mathbf{p}<\mathbf{0 . 0 5}$ & $\mathbf{p}<\mathbf{0 . 0 1}$ \\
Total other & $\mathbf{p}<\mathbf{0 . 0 1}$ & Ns & Ns & $\mathbf{p}<\mathbf{0 . 0 5}$ & Ns \\
Luciferid & Ns & Ns & Ns & Ns & Ns \\
Portunid/grapsid & $\mathbf{p}<\mathbf{0 . 0 5}$ & Ns & Ns & Ns & Ns \\
Ocypodid & $\mathbf{p}<\mathbf{0 . 0 5}$ & Ns & Ns & $\mathbf{p}<\mathbf{0 . 0 5}$ & Ns \\
Xanthid & Ns & Ns & Ns & Ns & Ns \\
Non-identified brachyuran & Ns & Ns & Ns & Ns & Ns \\
\hline
\end{tabular}

Ns = Not significant

Table 2 - Analysis of variance (Anova) of density (ind. $\mathrm{m}^{-3}$ ) in response to depth, diurnal and tidal cycles, and their interactions in summer samples. Significant relations are marked with $\mathrm{p}$ level.

\begin{tabular}{lccccc}
\hline & Depth & Light & Tide & Depth/Light & Depth/Tide \\
\hline Total decapod & $\mathbf{p}<\mathbf{0 . 0 1}$ & $\mathbf{p}<\mathbf{0 . 0 5}$ & Ns & Ns & Ns \\
Total brachyuran & $\mathbf{p}<\mathbf{0 . 0 1}$ & Ns & Ns & $\mathbf{p}<\mathbf{0 . 0 5}$ & Ns \\
Total other & Ns & $\mathbf{p}<\mathbf{0 . 0 5}$ & Ns & $\mathbf{p}<\mathbf{0 . 0 5}$ & Ns \\
Luciferid & Ns & $\mathbf{p}<\mathbf{0 . 0 5}$ & Ns & Ns & Ns \\
Portunid/grapsid & $\mathbf{p}<\mathbf{0 . 0 1}$ & $\mathbf{p}<\mathbf{0 . 0 5}$ & Ns & $\mathbf{p}<\mathbf{0 . 0 5}$ & Ns \\
Ocypodid & $\mathbf{p}<\mathbf{0 . 0 1}$ & $\mathbf{p}<\mathbf{0 . 0 5}$ & Ns & $\mathbf{p}<\mathbf{0 . 0 5}$ & Ns \\
Xanthid & $\mathbf{p}<\mathbf{0 . 0 1}$ & Ns & $\mathbf{p}<\mathbf{0 . 0 5}$ & $\mathbf{p}<\mathbf{0 . 0 5}$ & Ns \\
Non-identified brachyuran & $\mathbf{p}<\mathbf{0 . 0 1}$ & Ns & $\mathbf{p}<\mathbf{0 . 0 5}$ & Ns & $\mathbf{p}<\mathbf{0 . 0 5}$ \\
\hline
\end{tabular}


Table 3 - Analysis of variance (Anova) of density (ind. $\mathrm{m}^{-3}$ ) in response to seasonal cycle (Season) and the interaction with depth (S/D - Season/Depth), tide (S/T - Season/Tide) and light (S/L - Season/Light).

\begin{tabular}{lcccc}
\hline & Season & S/D & S/T & S/L \\
\hline Total decapod & $\mathbf{p}<\mathbf{0 . 0 5}$ & Ns & Ns & $\mathbf{p}<\mathbf{0 . 0 5}$ \\
Total brachyuran & $\mathbf{p}<\mathbf{0 . 0 5}$ & Ns & Ns & Ns \\
Total other & Ns & Ns & Ns & $\mathbf{p}<.05$ \\
Luciferid & Ns & Ns & $\mathbf{p}<\mathbf{0 . 0 5}$ & $\mathbf{p}<\mathbf{0 . 0 5}$ \\
Portunid/grapsid & Ns & Ns & Ns & Ns \\
Ocypodid & Ns & Ns & Ns & Ns \\
Xanthid & Ns & Ns & Ns & Ns \\
Non-identified brachyuran & Ns & Ns & Ns & Ns \\
\hline
\end{tabular}

Among the L. faxoni sampled, the following stages were identified: protozoeae, juveniles, adult females (few ovigerous), and adult males (Cardoso, 2000). All the other non-brachyuran and non-luciferid decapod larvae found constituted a low-density group called "other decapod". The total density of the "other decapod" group was similar to that for L. faxoni, in that high densities occurred during the night at the surface and during the day near the bottom in winter. The same result was not found during the summer. Two high densities occurred during nocturnal ebb tides.

Densities of $L$. faxoni and "other decapod" were associated with depth and with season / light interaction. L. faxoni was the only group that showed significant changes in population density in response to season and tide (Tab. 3).

\section{DISCUSSION}

Decapods by staying high in the water column during flood tides have found an efficient way to reach the shelf quickly (Saigusa, 1981). High densities of decapod crustacean larvae in surface waters during ebb tides support a hypothesis of larval transport from Guanabara Bay to the shelf coastal areas. Portunid (e.g. Callinecte), ocypodid (e.g. Uca) and cancrid (e.g. Cancer) larvae are commonly exported from estuaries to adjacent coastal areas (Epifanio et al., 1989; Epifanio, 1996). High densities of portunid / grapsid zoeae found in this study at the surface during ebb tides, when the velocities of transport should be fast (see McConaugha, 1988), suggest the same pattern of dispersion toward oceanic waters. Portunid and cancrid zoeae have a high-salinity requirement for complete larval development (Epifanio and Dittel, 1984). As such, being exported to oceanic water is an ecological strategy to find optimal conditions for development. In addition, this strategy avoids high predation rates common in estuaries (Morgan and Christy, 1997).

Ocypodids are believed to follow the same strategy because they were abundant at the same time as the portunids / grapsids. These results support the hypothesis of a dispersion strategy to the coastal adjacent waters. In Paranaguá Bay (Brazil), Freire (1998) found a similar dispersion strategy for Ucides cordatus to adjacent coastal waters. However, Sandifer (1975) suggested that retention in estuarine waters may be due to species specific behaviour.

In this study, unlike the portunids / grapsids and ocypodids, xanthids and luciferds did not show the same pattern of distribution in winter and summer. In the summer, xanthids and luciferids were exported from Guanabara Bay during nighttime ebb tides, as were the portunids / grapsids and ocypodids. In contrast, in the winter, xanthids were homogeneously distributed throughout the water mass, while luciferids were retained in the bay or imported from adjacent coastal waters. It is not clear yet if these distribution patterns represent family group strategies, because they may be related to occasional or to seasonal disturbances. In the first case, changes in vertical distribution are unpredictable. In Guanabara Bay, cold weather fronts cause occasional disturbances in vertical distribution and account for the high density of Lucifer faxoni near the bottom during the winter. In the second case, a seasonal pattern of distribution can be explained by the seasonal changes in salinity and temperature in Guanabara Bay (Paranhos et al., 1993). In contrast, Lochmann et al. (1995) didn't find evidence to support links between tidal and diurnal changes and the vertical distribution of crab larvae (Callinectes sapidus).

In our study, we found significant differences in the seasonal distribution of Lucifer faxoni. 
Whether this difference was related to the marked seasonal variation in salinity and temperature is yet unclear. However, we could suggest a seasonal distribution pattern for $L$. faxoni as follows: in the winter, larval stages are imported into Guanabara Bay to complete their development inside estuary, and in the summer non-reproductive adults are exported to the shelf waters. In Guanabara Bay, the vertical distribution of decapod larvae are related to environmental conditions, as light and tide. Portunids / grapsids and ocypodids follow the same predictable pattern of dispersion toward the adjacent coastal waters, while for the luciferids and xanthids larvae, that pattern of distribution still remains unclear.

\section{ACKNOWLEDGEMENTS}

The autors would like to thank Drs. Andrew Macrae, Ralf Schwamborn and Ana Bonecker for the suggestions and review of English text, and $\mathrm{CNPq}$ for financial support.

\section{RESUMO}

Larvas de crustáceos decápodes são organismos planctônicos comuns tanto em regiões costeiras rasas como em estuários. Nesse trabalho, foi acompanhada a variação da densidade das larvas de decápodes num ponto estratégico entre a porção interior da baía de Guanabara e a região costeira adjacente. A coleta de grandes quantidades de zoés de braquiúros, principalmente das famílias Portunidae e Grapsidae, na superfície durante as marés de vazante noturnas sugere uma tendência de exportação para a região costeira adjacente. A repetição desse padrão no inverno e no verão demonstrou que as respostas dos organismos às variações de luz e maré não foram alteradas de modo significativo entre as duas estações do ano, exceto para os luciferídeos. O fluxo observado para a única espécie de luciferídeo capturada (Lucifer faxoni) foi significativamente diferente entre os dois períodos do ano analisados. É provável que essas diferenças na distribuição de Lucifer faxoni seja relacionada ao ciclo reprodutivo da espécie. Foi observado um padrão de dispersão similar para as larvas zoé dos portunídeos, grapsídeos e ocypodídeos; transporte para a região costeira adjacente pela superfície durante as marés de vazante noturnas.

\section{REFERENCES}

Almeida, M. C. M. (1993), Estudo sobre a pesca do camarão realizada pela colônia de pesca da Ilha do Governador na Baía de Guanabara, Rio de Janeiro. Bachelorship Monograph, Estadual University of Rio de Janeiro, Brazil.

Amador, E. S. (1997), Baía de Guanabara e ecossistemas periféricos: Homem e Natureza. Reproarte, Rio de Janeiro. 539pp.

Cardoso, I. A. (2000), Migração Vertical de Lucifer faxoni Borradaile, 1915 (Crustacea, Decapoda) em resposta aos ciclos circadiano e de marés na Baía de Guanabara - RJ (Brasil). Bachelorship Monograph, Federal University of Rio de Janeiro, Brazil.

Epifanio, C. E. (1988), Transport of invertebrate larvae between estuaries and the continental shelf. Am. Fish. Soc. Symp., 3, 104-114.

Epifanio, C. E. (1996), Transport of blue crab (Callinectes sapidus) larvaein the waters off MidAtlantic States. Bull. Mar. Sci., 57, 713-725.

Epifanio, C. E. and Dittel, A. I. (1984), Seasonal abundance of brachyuran crab larvae in a tropical estuary: Gulf of Nicoya, Costa Rica, Central America. Estuaries, 7 : (4B), 501-505.

Epifanio, C. E.; Masse, A. K. and Garvine, R. W. (1989), Transport of blue crab larvae by surface currents off Delaware Bay, USA. Mar. Ecol. Progr. Ser., 54, 35-41.

Freire, A. S. (1998), Dispersão larval do caranguejo do mangue Ucides cordatus (L. 1763) em manguezais da Baía de Paranaguá, Paraná. PhD Thesis, Universidade de São Paulo, Brazil.

Ibanez, F. (1976), Contribution à l'analyse mathématique des évènements en ecologie planctonique. Bull. Inst. Océanogr., 72 (1431), 1-96.

Kjerve, B.; Ribeiro, C. H. A.; Dias, G. T. M.; Filippo, A. M. and Quaresma, V. S. (1997), Oceanographic characteristics of an impacted coastal bay: Baía de Guanabara, Rio de Janeiro, Brazil. Continental Shelf Research, 17 : (13), 1609-1643.

Lochmann, S. E.; Darnell, R. M. and McEachran, J. D. (1995), Temporal and vertical distribution of crab larvae in a tidal pass. Estuaries, 18(1B), 255-263.

McConaugha, J. R. (1988), Export and reinvasion of larvae as regulators of estuarine decapod populations. Am. Fish. Soc. Symp., 3, 90-103.

Morgan, S. G. and Christy, J. H. (1997), Planktivorous fishes as selective agents for reproductive synchrony. Journal of Experimental Biology and Ecology, 209, 89-101. 
Nogueira, C. R.; Bonecker, S. L. C. and Bonecker, A. C. T. (1989), Zooplâncton da Baía de Guanabara (RJ-Brasil) - Composição específica e variações espaço-temporais. Paper presented at III Encontro Brasileiro de Plâncton, 5-9 December, Caiobá (PR), Brazil.

Oliveira, L. P. H. (1962), Estágios larvários do caranguejo "catanhen" Chasmagnathus granulata Dana, 1851 (Crustacea, Grapsidae). Mem. Inst. Oswaldo Cruz, 60 : (2), 257-262.

Paranhos, R. and Mayr, L. M. (1993), Seasonal patterns of temperature and salinity in Guanabara Bay, Brazil. Fresenius Environm. Bull., 2, 647-652

Saigusa, M. (1981), Adaptive significance of a semilunar rhythm in the terrestrial crab Sesarma. Biol. Bull., 160, 311-321.

Sandifer, P. A. (1975), The role of pelagic larvae in recruitment to populations of adult decapod crustacean in the York River estuary and adjacent lower Chesapeake Bay, Virginia. Estuar. Coast. Mar. Sci., 3, 269-279.

Schwamborn, R. (1993), Floating mangroves leaves used for transportation and diet of decapod larvae in a Brazilian estuary. MSc Thesis, MathematischNaturwissenschaftliche Fakultät der ChristianAlbrchts-Universität zu Kiel, Kiel, Germany.
Siegel, S. (1975), Estatística Não-Paramétrica para as Ciências do Comportamento. São Paulo : McGraw-Hill. Stancyk, S. E. and Feller, R. J. (1986), Transport of non-Decapod invertebrate larvae in estuaries: an overview. Bull. Mar. Sci., 39 : (2), 257-268.

Valentin, J. L.; Tenenbaum, D. R.; Bonecker, A. C. T.; Bonecker, S. L. C.; Nogueira, C. R. and Villac, M. C. (1999), O Sistema Planctônico da Baía de Guanabara: Síntese do Conhecimento. In: Silva, S. H. G. and Lavrado, H. P. (eds.). Ecologia dos Ambientes Costeiros do Estado do Rio de Janeiro. (Série Oecologia Brasiliensis; 7). PPGE-UFRJ, Rio de Janeiro, Brasil.

Wolanski, E. and Sarsenski, J. (1997), Larvae Dispersion in Coral Reefs and Mangroves. American Scientist, 85, 236-243.

Received: June 26, 2000; Revised: April 16, 2001; Accepted: January 18, 2002. 